\title{
DO DOIS AO TRÊS EM JOÃO CABRAL ${ }^{*}$
}

http:/ / dx.doi.org/10.11606/issn.2237-1184.v0i30p193-221

Ariovaldo Vidal ${ }^{\mathrm{I}}$

\section{RESUMO}

Em sua primeira parte, o ensaio descreve brevemente a resenha que Antonio Candido dedicou ao livro de estreia de João Cabral de Melo Neto, Pedra do sono (1942), publicada no ano seguinte com o título de "Poesia ao Norte", e recolhida hoje no livro Textos de intervenção (2002), mostrando a admiração mútua entre poeta e crítico. Na parte central, o ensaio procura analisar o poema de João Cabral "Duas das festas da morte", do livro A educação pela pedra (1966), a partir do ensaio de Antonio Candido "A passagem do dois ao três" (1974), recolhido também no livro citado, mostrando a possibilidade de leitura de um movimento dialético entre as duas estrofes do poema. E na parte final, um breve comentário ao poema que dá título ao livro de Cabral, comentado no mesmo sentido do anterior.

\section{ABSTRACT}

In its first part, the essay shortly describes the review that Antonio Candido dedicated to the debut book by João Cabral de Melo Neto, Pedra do sono (1942), published in the following year entitled "Poesia ao Norte", and collected these days in the book Textos de intervenção (2002), showing the mutual appreciation between the poet and the critic. In its central part, the essay seeks to analyze João Cabral poem "Duas das festas da morte", from the book A educação pela pedra (1966) in the essay by Antonio Candido "A passagem do dois ao três" (1974), ability to read a dialectical movement between the two strophes of the poem. And in its final part, a brief comment to the poem that provides the title to the book by Cabral, commented in the same sense of the previous.

\section{PALAVRAS-CHAVE:}

Antonio Candido;

"A passagem do dois ao três" João Cabral de Melo Neto; A educação pela pedra.

\section{KEYWORDS}

Antonio Candido;

"A passagem do dois ao três"; João Cabral de Melo Neto; A educação pela pedra.

* Uma primeira versão desta leitura foi apresentada em 2013, no Congresso da ABRALIC de Campina Grande (PB), com o título "Horror à brasileira"; antes disso, trabalhei várias vezes com o poema em sala de aula, circunstância que muito me auxiliou na leitura do texto.

I Universidade de São Paulo, São Paulo, São Paulo, Brasil. 
Não é pelo vício da pedra, por preferir a pedra à folha.

É que a cabra é expulsa do verde, trancada do lado de fora.

“Poema(s) da cabra", in Quaderna

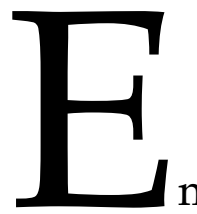

m mais de uma ocasião, Antonio Candido (1918-2017) demonstrou sua admiração pela poesia de João Cabral (19201999), dizendo mesmo considerá-lo um dos maiores poetas do século XX. A lembrança da frase não tem o propósito laudatório (e ingênuo), antes de começar a falar de sua obra que parece andar um tanto por baixo em mais de um setor da crítica; o próprio poeta "revolucionado" sabia disso, pois ainda em 1985 abria seu livro Agrestes chamando atenção para o fato de que sua poesia ria "de ser sem discípula", vendo outra banda desfilar. ${ }^{1} \mathrm{O}$ propósito de lembrar a frase é simplesmente registrar a admiração (recíproca) que Antonio Candido nutria por João Cabral; digo mesmo que entre crítico e poeta havia mais de uma afinidade profunda, das quais um aspecto ou outro pode aparecer neste ensaio, que não tem exatamente esse propósito como primordial.

O interesse maior destas páginas é ler um poema de Cabral a partir de um ensaio de Candido, a fim de compreender o trabalho rigoroso do poeta na representação da matéria social brasileira, bem como demonstrar o alcance do ensaio enquanto instrumento de leitura e interpretação. Tratase de uma análise do poema "Duas das festas da morte", de A educação pela pedra (1966), feita com o apoio do ensaio "A passagem do dois ao três", publicado em periódico e, posteriormente, recolhido no livro Textos de intervenção (2002). Na parte final do ensaio, comento brevemente outro poema do livro, a fim de avaliar o alcance do ensaio de Candido. Mas antes de entrar no poema de Cabral, é preciso mencionar alguns aspectos da antológica resenha que o crítico escreveu por ocasião da estreia do poeta, sem o que o diálogo dos dois ficaria incompleto.

1 "A Augusto de Campos", in Agrestes. 


\section{De Candido a Cabral}

Ao publicar seu livro de estreia - Pedra do sono (1942), em edição do autor - , João Cabral consegue que no ano seguinte seu livro chegue às mãos do crítico paulista através de um amigo comum. Tendo conhecido o livro, Candido resolve resenhá-lo junto com outro volume que lhe chegara às mãos do também jovem poeta Rui Guilherme Barata, chamado Anjo dos abismos (1943), publicado pela José Olympio; e devido à procedência dos dois poetas (Rui era do Pará), dá à resenha o título de "Poesia ao Norte". ${ }^{2}$

Ao livro de Rui Barata, será dedicada a parte final da resenha, quando Candido comenta que seu livro de estreia revela por inteiro uma identificação profunda com a poesia de Augusto Frederico Schmidt. Vista de hoje, parece que a trajetória de Rui é de algum modo similar à de Vinicius de Moraes (sem considerar o valor das obras) pois, como este, Rui também passou dessa poesia de "halo majestoso", sob influência de um mesmo mestre, à poesia participante na década seguinte e, posteriormente, à canção popular.

Mas ficando na obra de Cabral, que ocupa a quase totalidade da resenha, quero me deter em dois ou três comentários de Candido, que terão consequências na obra posterior do autor, deixando de lado várias expressões sugestivas do texto; tanto que o próprio Cabral elogiará mais de uma vez a resenha, que qualificou de "artigo admirável", dizendo que o crítico percebeu tudo o que era e o que seria sua poesia dali em diante. Numa de suas entrevistas, o poeta deixa clara sua admiração pelo crítico, trecho que vale a pena reproduzir:

[...] quando o meu primeiro livro saiu, eu estava no Recife. Eu conhecia o Antonio Candido de nome, ele já morava em São Paulo e já fazia crítica literária. Eu mandei para ele o livro Pedra do sono, sobre o qual ele publicou uma crítica no jornal Folha da Manhã [...] Mas eu lá do Recife nem sabia da existência desse jornal - Folha da Manhã - e não tinha lido esse artigo. Quando eu vim para o Rio, um dia conversando com Carlos Drummond ele citou esse artigo de Antonio Candido. Hoje eu poderia colocálo como prefácio em minhas poesias completas porque ele previu tudo o que eu ia escrever, a maneira como eu ia escrever e meu primeiro livro não é ainda muito característico da minha maneira posterior, mas ele pressentiu tudo. Notou que minha poesia aparentemente surrealista, no fundo, era a poesia de um cubista. De fato, de todas as escolas, estilos de pintura, a coisa que mais me influenciou, mais me marcou foi o Cubismo. Daí também essa grande influência de Le Corbusier. O Antonio Candido

\footnotetext{
${ }^{2}$ A resenha foi publicada no jornal Folha da Manhã, São Paulo, 13 jun. 1943; depois de algumas republicações, encontra-se recolhida no citado Textos de intervenção (2002, p. 135-42). O modo como o livro chegou às mãos do resenhista está contado pelo próprio Candido num breve artigo para a Folha de S. Paulo (1999, p. 4) por ocasião da morte de Cabral. Agradeço a Edu Teruki Otsuka pela lembrança do artigo.
} 
previu esse meu construtivismo, essa minha preocupação de compor o poema, de não deixar que o poema se fizesse sozinho, de falar das coisas e não de mim. (ATHAYDE, 1998, p. 100-1)

Se Candido pressentiu com tamanha clareza a verdadeira feição de sua poesia já naquele momento - dizendo ser uma composição de caráter pictórico, feita de "objetos precisos", em que as palavras ganham um "valor plástico" - , o fez de uma maneira que sugeria vários aspectos que se tornariam decisivos da poética do autor. Além desse construtivismo que o crítico percebeu por dentro do tecido surrealista - e, de fato, Cabral dirá mais tarde que Le Corbusier o "curou" do surrealismo - , Candido fará um comentário dos mais decisivos para compreender a poesia de Cabral, cujo trecho cito abaixo:

Não se conclua porém que esta poesia seja um edifício racionalista. Muito pelo contrário, o trabalho ordenador a que é devida se exerce sobre os dados mais espontâneos da sensibilidade. Daí a riqueza do livro, que alia a ordenação da inteligência ao que há de mais essencialmente espontâneo no homem. (CANDIDO, 2002, p. 137)

Como bom crítico dos avessos, Antonio Candido percebeu de imediato uma condição decisiva da poesia de Cabral: que por dentro da simetria toda que marcava aquele construtivismo, havia a matéria humana, o que há de "mais essencialmente espontâneo no homem", condição que será decisiva para que em toda sua poesia, mesmo quando não fale do homem e, sim, dos objetos, ela esteja sempre impregnada do humano, como dirá mais tarde um de seus críticos. ${ }^{3}$ Não é por outra razão a presença constante e decisiva da natureza na poesia do autor - uma nostalgia discreta e intensa de um vínculo perdido entre homem e natureza -, da qual o homem tanto se afasta, mas para a qual todo o universo de seres e coisas de Cabral parece se voltar, resgatada na beleza vista e vivida pelo olhar que admira a forma perfeita do ovo de galinha, e de tantos seres, num movimento que sonha recuperar uma extensão espontânea entre o homem e sua paisagem - como aparece na estrada de Caxangá, onde tudo passa ou já passou, com "namorados que passeiam/ amadurecendo o amor". 4

Essa presença visceral das coisas mais espontâneas e naturais do homem é levada ao limite em sua obra, com uma consciência aguda de dois temas decisivos em sua poesia - a morte e o tempo. No caso da morte, há uma presença tão extensa em seus poemas que o próprio poeta fala disso, dedicando a ela seções de livros; conta mesmo um episódio em que foi

\footnotetext{
${ }^{3}$ Refiro-me ao comentário de Luiz Costa Lima (1995, p. 222) a propósito do belo poema "A mesa", de $O$ engenheiro (1945), ao dizer que na poesia de Cabral a presença dos objetos implica a presença do homem, através dos quais "ele pratica e objetiva sua humanidade".

4 "O motorneiro de Caxangá", in Quaderna.
} 
consultar-se em Madrid com um “Grão-Doutor" que pediu para ler seus poemas e, na semana seguinte, volta com a resposta: falar tanto da morte é exorcismo, parece-lhe, pois "é o pavor da morte, da sua,/ que o faz falar da do Nordeste" .5

Não é só por isso que ele falará da morte no Nordeste, mas de fato acabará falando da sua também em versos contundentes, que traem uma consciência aguda da condição finita do homem, como aqueles de "Autobiografia de um só dia", em que o poeta se põe a contar o episódio de seu nascimento: "Porém em pleno Céu de gesso,/ naquela madrugada mesmo,// nascemos eu e minha morte" ${ }^{6}$ E a consciência do tempo aparece, entre tantos poemas, em versos pontiagudos como aqueles dedicados à obra final de Marques Rebelo - "O espelho partido": seu romance-rio é visto pelo poeta como um câncer: "câncer que leva outro mais dentro,/ o câncer do câncer, o tempo" . ${ }^{7}$

Nessa composição entre o simétrico e geométrico com a espontaneidade - que vai criar na obra do poeta o gosto dos oxímoros, que buscam traduzir esse extremo formado pelos opostos - , talvez a melhor definição da poética de João Cabral tenha vindo do próprio Candido, não ao falar do autor e, sim, de seu próprio trabalho. No tópico dos "Pressupostos" da Formação, ao falar do modo como entende o trabalho do historiador da literatura num sentido moderno, livre do determinismo dos velhos compêndios e de uma atitude esteticista, Antonio Candido vê o trabalho do historiador num "equilíbrio instável" entre a individualidade da obra que se impõe e o quadro geral que ordena. Ao definir esse trabalho, o crítico afirma que ele busca "o máximo de vida com o máximo de ordem mental" (CANDIDO, 1975, p. 31), o que se resolve na forma daquele "equilíbrio instável" (Cabral dirá "equilíbrio leve"), condição que se traduz na figura do oxímoro, momentaneamente enlaçando os contrários numa unidade tensa. A composição desses contrários não deixa de levar a vida até o limite pois, se não abre mão do rigor, não deixa também de olhar para o horizonte como a vida na sua maior amplitude - o "rigoroso horizonte" do verso de Guillén. E quantos seres cabralinos não viverão a vida no limite: a bailarina feita de borracha e pássaro, que dança "nas secretas câmaras/ que a morte revela"; a bailadora andaluza, que também dança com o "gosto dos extremos,/ de natureza faminta"; e o toureiro espanhol, "o que com mais precisão/ roçava a morte em sua fímbria" .8

Mas há um comentário em especial de Candido que deve ser mencionado, pois dará ensejo a que entremos no tópico seguinte deste

\footnotetext{
5 "O exorcismo", in Crime na calle Relator.

6 "Autobiografia de um só dia", in A escola das facas.

7 "O espelho partido", in Museu de tudo.

8 Respectivamente, "A bailarina", in O engenheiro; "Estudos para uma bailadora andaluza", in Quaderna; "Alguns toureiros", in Paisagens com figuras.
} 
ensaio: refiro-me ao fato de o crítico, depois de ter atinado com o projeto de base mallarmiana do jovem poeta, ter mostrado preocupação com a obsessão deste pela poesia pura, não somente pelo perigo de seu barco "ficar pelos escolhos" sem "alcançar as estrelas", mas também pelo perigo implicado na pureza, de esta ressecar de algum modo a vida. E o fecho da resenha (no tocante a Cabral) é uma espécie de conselho e vaticínio que traz a marca da experiência, combustível de um grande crítico:

O sr. Cabral de Melo, porém, há de aprender os caminhos da vida e perceber que lhe será preciso o trabalho de olhar um pouco à roda de si, para elevar a pureza da sua emoção a valor corrente entre os homens e, deste modo, justificar a sua qualidade de artista. (CANDIDO, 2002, p. 141)

Com referência à poesia de Mallarmé, a despeito de sua admiração pelo poeta, Cabral dirá no entanto que ela "conduziu a um beco sem saída" (ATHAYDE, 1998, p. 135); e todo o trabalho posterior do autor de Pedra do sono será o de conquistar a realidade social e transformá-la em matéria de poesia. Cito um depoimento do próprio poeta para mostrar sua disposição naquele momento, aliás bastante injusto consigo mesmo:

Depois, compreendi que aquilo era um beco sem saída, que poderia passar o resto da vida fazendo esses poeminhas amáveis, requintados, dirigidos especialmente a certas almas sutis. Foi daí que resolvi dar meia-volta e enfrentar esse monstro: o assunto, o tema. O cão sem plumas, meu livro seguinte, escrito em Barcelona, foi a consequência (ATHAYDE, 1998, p. 104).

\section{De Cabral a Candido}

Conta João Cabral que, ao ler certo dia uma matéria sobre a expectativa de vida no Nordeste assolado pela fome, resolveu lançar-se sobre a folha em branco e, vencendo uma dificuldade que o acompanhava desde o início ainda com pretensões à poesia pura, encarar definitivamente o tema - "esse monstro" - que o aterrorizava. ${ }^{9}$ Mesmo sendo o depoimento do próprio poeta, tudo deve ser relativizado: seguramente não foi só a matéria que mostrava o horror da miséria que o moveu ou demoveu da poesia anterior, a que o poeta chamava injustamente de "onanista", nem sua poesia fora inteiramente pura alguma vez. Mas era fato que sofria com não saber dizer certas coisas em verso e que, naquele momento, sua consciência o chamava para a participação da poesia na vida social, num ambiente em que a figura decisiva de Drummond, por exemplo, lhe dizia em correspondência que era preciso levar a poesia ao povo, aos operários, aos pequenos funcionários públicos (SÜSSEKIND,

${ }_{9}$ O fato está contado na entrevista a Antonio Carlos Secchin (1985, p. 302). 
2001, p.174), num momento decisivo de aproximação do poeta ao pensamento marxista, com consequências para sua vida e obra.

O certo é que, a partir de O cão sem plumas (1950) - poema-livro que recebeu uma bela leitura fotográfica de Maureen Bisilliat (MELO NETO, 1984) - , Cabral irá cada vez mais e intensamente incorporar ao seu temário a condição espoliada do homem nordestino sujeito à seca e abandono, em versos sempre contundentes e secos, com seu instrumento de trabalho desbastando as palavras crestadas pelo sol. Essa incorporação temática coincide também com uma definição maior de seu estilo, forjado durante aqueles anos em que esteve na Espanha pelo serviço diplomático, quando conhece a poesia do romanceiro medieval, incorporando de vez a seus versos a imagem prosaica e concreta, o verso curto, a rima toante, que marcarão sua obra na década de 50 e dali por diante. ${ }^{10}$ Ao ser publicado o poema-livro mencionado, que fala do rio Capibaribe e sua população indigente, uma colega que gostava do poema disse-lhe, entretanto, que havia no poema coisas violentas, ao que o poeta teria respondido: "Violento vai ser quando o rio falar" (FREIXIEIRO, 1971, p. 189).

Assim, logo depois do poema de 50, Cabral fará o rio falar no poema narrativo que incorpora definitivamente em sua poesia a forma do romance espanhol, influência que o acompanhará por toda a obra; depois será a vez de o retirante contar sua morte e vida, incorporando também a poesia popular do Nordeste, e dali em diante tantas outras vozes falarão seu canto a palo seco, em sua voz sem saliva, denunciando a realidade violenta num registro que oscila entre a notação indignada e dura nos versos secos, de um lado, e a frase também seca mas dotada de uma verve irônica, mordaz, incorporando a desfaçatez de uma elite "fundassentada" na modorra dos casarões servidos por mãos ainda escravas. Nessa mudança decisiva que ocorrerá em sua obra nos anos 50, não é exagero ler a duplicidade implicada nos versos a seguir como também uma atitude diante da poesia: num dos poemas da série dos "cemitérios pernambucanos", o poeta dirá: "É cemitério marinho/ mas marinho de outro mar" ${ }^{11}$ Não passa despercebida ao leitor a referência ao poema de Valéry, como que marcando uma condição diversa para esse outro "cemitério marinho" que está à frente de seus olhos; e o que é importante também, dizendo essa outra realidade sem deixar de ser valeriano.

Coloca-se para o leitor o problema de saber exatamente o lugar desse ponto de vista que, inegavelmente, aponta com toda contundência a miséria da paisagem física e humana. Às vezes, a memória afetiva (e contraditória) faz que o "menino de engenho" relembre - sempre no

\footnotetext{
${ }^{10}$ Esses breves comentários não têm intenção de descrever o processo todo da poesia do autor, de resto bastante tratado por sua melhor crítica, com a influência também dos poetas brasileiros, das artes visuais, da arquitetura e pensamento de Le Corbusier, Valéry etc.; trata-se apenas de pontuar uma mudança significativa em sua obra, para chegar ao tema decisivo que nos interessa por agora.

11 “Cemitério pernambucano (São Lourenço da Mata)”, in Paisagens com figuras.
} 
registro enunciativo e nada confessional - o passado em que a cana dos banguês era dócil e "clássica", ordem linear e precisa destruída pela modernidade das usinas, como no poema justamente intitulado "Moenda de usina" ${ }^{12}$ Outras vezes - muitas vezes - a realidade agreste (e agressiva) dará ao homem que fala pelo seu lápis lições importantes de vida, sobretudo num mundo cada vez mais devorado pelo consumo, para o qual o engenheiro que "sonha coisas claras" colocará seu sonho e ciência a favor da construção do mínimo e essencial copo de água.

A situação se problematiza mais quando esse olhar que tira de seres e pedras lições de vida e poesia elide a causa dos problemas, dirigindo o olhar para a resistência levada ao limite em que o homem pobre, tragicamente, mostra sua grandeza inútil. Tome-se como exemplo o belo "Pregão turístico do Recife": nele há três lições fundamentais que o poetaguia ensina ao leitor-turista: a primeira, extraída da natureza (fonte de todas as lições), é o fio de luz precisa, matemática e metal que mostra a resistência do mínimo que, por reduzido ao essencial, ganha a plenitude de seu contrário aqui e em tantos lugares expresso pelos belos oxímoros que marcam o estilo de Cabral: é um fio de luz, mas com a consistência do metal. A segunda lição já supõe a ação humana, que imita a natureza que a cerca: os velhos sobrados esguios que se equilibram levemente desde longa data; e não será difícil ver nessa arquitetura a inspiração corbusieriana que tanto influenciou Cabral, o arquiteto-pintor que lhe ensinou que o poema é uma máquina de comover e que "a paixão faz das pedras inertes um drama" (LE CORBUSIER, 1977, p. 103). Mas a terceira lição, a mais intensa e difícil, é a que a frágil criatura humana ensina ao chafurdar-se na lama podre do mangue, em que todas as metáforas reduzidas ao essencial falam de doença e morte, mas que, por isso mesmo, levam a resistência da vida ao limite; lição bela sem dúvida, mas imposta pela violência de uma classe que passa quase ao largo do poema, ainda que não se possa deixar de reconhecer a contundência da denúncia.

Não se pode deixar de dizer também que essa categoria da resistência é central na poética de Cabral e notável em relação a vários temas e situações, especialmente ao tempo - afinal, se é preciso imitar a pedra, parte-se do pressuposto de que o homem é um ser frágil; e justamente dessa condição Cabral retirará matéria e perspectiva para alguns de seus melhores poemas pois, ao invés de lamentar o tempo que passa, cantará a resistência do homem e seu "motor", funcionando até a última gota. ${ }^{13}$

Mas há outros casos em que a representação da miséria vem destituída de qualquer recompensa moral, com toda sua carga de degradação. Nesses casos como nos demais, o poeta mostra ter domado o monstro com mão serena e segura como a do toureiro Manolete, criando a um só tempo a impressão de uma realidade que chega ao leitor sem filtro

12 In A escola das facas.

13 "O relógio", in Serial. 
algum - o sol de Pernambuco e, ainda assim, com a linguagem densa de uma poesia que se depura e pensa a cada passo; bastará recordar a série de seus "Cemitérios pernambucanos", os versos de Dois parlamentos, ou de poemas como "Alto do Trapuá", "Volta a Pernambuco" e outros mais. Nesses casos, a mediação simbólica da forma poética aparece em sua espessura estética, ao mesmo tempo deixando ver do outro lado a realidade que se ilumina indigna.

Feita a breve apresentação da antológica resenha que Candido dedicou a Cabral, e breves comentários acerca de um momento decisivo para a poesia deste, quero agora fazer o caminho inverso (ou melhor, de mão dupla), lendo um poema de Cabral que se oferece como possibilidade de diálogo com a obra de Candido, a partir de uma formulação do crítico quanto a seu método de leitura, o que ajudará a colocar em maior evidência as tensões do universo do autor pernambucano no que se refere ao tratamento das tensões de classe social. Trata-se de um dos poemas mais duros do autor - "Duas das festas da morte" - , presente em A educação pela pedra, abordando a realidade sem sentimentalismo, nem culpa retorcida: apenas o registro do absurdo; e se o intelectual acreditou alguma vez nas promessas e propaganda do desenvolvimentismo, o artista procurou corrigi-lo, pois o poema é expressão de um mundo estagnado. Vejamos mais de perto esse caso, presente no livro em que Cabral apostou alto, com poemas de uma sintaxe grave, cada um deles trazendo a marca pétrea do título.

Duas das festas da morte

Recepções de cerimônia que dá a morte: o morto, vestido para um ato inaugural; e ambiguamente: com a roupa do orador e a da estátua que se vai inaugurar.

No caixão, meio caixão meio pedestal, o morto mais se inaugura do que morre; e duplamente: ora sua própria estátua, ora seu próprio vivo, em dia de posse.

*

Piqueniques infantis que dá a morte: os enterros de criança no Nordeste: reservados a menores de treze anos, impróprios a adultos (nem o seguem). Festa meio excursão meio piquenique, ao ar livre, boa para dia sem classe; nela, as crianças brincam de boneca, 
e, aliás, com uma boneca de verdade.

O poema segue o padrão das composições do livro em que se insere: formado de duas grandes estrofes, em número quaternário de versos (neste caso, as duas com oito versos), todos compostos com rimas toantes, cujo esquema supõe a rima apenas nos versos pares. Quanto ao metro, os versos variam em torno de doze sílabas, o que se contrapõe aos versos geralmente curtos das demais obras. Como notou Antonio Candido (2004, p. 79-80), em nossos poetas modernos (e comum em Cabral) ocorre uma oscilação métrica sem prejudicar o efeito final do ritmo; ao contrário. ${ }^{14}$

Já no título, a voz lírica estabelece distinções que vão orientar a leitura das duas estrofes-festas. $\mathrm{O}$ "duas" refere-se diretamente à questão da ambiguidade e tensão do texto: se não estivesse no título, não haveria destaque para esse aspecto; mas por ser a primeira palavra - portanto, posta em destaque - , é indício de que o tema do poema está decisivamente ligado a essa dualidade e tensão; ou seja, uma "festa" depende, para ser entendida, da outra. Mas ao separar em duas estrofes, indicia também a distância entre as duas "festas", colocadas em situações extremas de um mesmo processo.

Há um caráter restritivo na expressão "duas das festas", pois o poema leva a inferir que há mais de duas "festas da morte", ou mesmo que há muitas: pode-se pensar, por exemplo, em todos os espetáculos em que é transformada a morte, como as execuções públicas etc.; ou mesmo em qualquer forma de ritual em que ela se dê; ou ainda pensar nos diferentes tratamentos e implicações da morte, especialmente como experiência traumática na vida privada do indivíduo, com a morte situada no âmbito do mistério existencial ou da indagação metafísica, dentro de certa tradição romântica. Ao falar em "duas das festas", e destacá-las do conjunto de situações da morte, o Eu contrapõe a essas outras possibilidades o tratamento que ele quer dar. ${ }^{15}$

O poema, portanto, abre mão de todas essas formas para restringirse a duas; assim, cria-se a noção de uma concentração, uma redução ao essencial, procedimento decisivo da linguagem poética; e mostra que

\footnotetext{
14 Para uma descrição dos aspectos formais do livro A educação pela pedra, ver o ensaio de Antonio Carlos Secchin (1985, p. 223 e ss.).

${ }^{15}$ Quanto ao lirismo de Cabral e ausência da voz em primeira pessoa, penso na pertinência do conceito de "enunciação lírica" desenvolvido por Wolfgang Kayser (1985, p. 376-77); certamente não há um Eu confessional nesse poema e, desde de seu livro de estreia, desde o poema que abre o livro, ficava claro que a confissão não era a praia do poeta (há um fato curioso, nesse sentido, a respeito da gênese do poema Uma faca só lâmina, registrado no livro de Félix de Athayde, 1998, p. 112); e mesmo quando se torna confessional, especialmente no livro A escola das facas, o faz de modo contido e equilibrado. Mas a voz que fala no poema é ainda uma voz lírica, mesmo com o afastamento implicado na relativa distância da enunciação; digo relativa distância porque mesmo um poema como esse, às voltas com o mundo prosaico e reificado, nasceu de um olhar intenso que se funde inicialmente à sua matéria; o leitor não deixará de perceber no poema não só esse olhar "lírico", intensamente tomado por seu objeto, como também uma voz lírica e pessoal, ainda que contida, que vê a cena na modulação de tons de sua indignação.
} 
naquele espaço apenas essas duas mortes (duas "festas") importam ou são decisivas para defini-lo.

Ocorre nesse caso de maneira evidente o efeito de estranhamento, conceito que vem especialmente dos formalistas russos, definido por Viktor Chklóvski em seu conhecido ensaio com algumas formulações que cabem já ao título do poema e se confirmarão pelos versos: uma dessas formulações refere-se ao ato de perceber o objeto fora de seu contexto e, neste caso, num contexto diametralmente oposto (a "morte" como "festa"), buscando dar à cena representada o efeito de uma visão reveladora, e não o reconhecimento do que é sabido. Para isso, não basta simplesmente a imagem oposta ("morte" como "festa"), mas todos os procedimentos formais que dão espessura estética ao texto, criando de algum modo o obscurecimento da forma (CHKLÓVSKI, 1971, p. 45 e 50). A metáfora que instaura o estranhamento no plano das imagens desdobra-se por todos os versos, do início ao fim, criando propriamente um plano alegórico no poema, como é comum na poesia de João Cabral, cujas imagens mantêm uma articulação orgânica no texto, submetidas sempre ao crivo crítico.

Ocorre um duplo paralelismo: dentro das estrofes (entre "morte" e "festa") e entre as estrofes (oposição entre as "festas"). Mas é preciso perceber que, em princípio, a metáfora pode não ser estranha, isto é, pode ser que a morte se aproxime mesmo da festa, sem haver nisso ironia (ou uma das faces da ironia); como também não haveria estranhamento nesse caso, pois esse, quando ocorre, é sempre de forma irônica. Talvez seja melhor dizer, em princípio, que a relação que se possa estabelecer entre morte e festa não possui um sentido fixo, sendo melhor mesmo acompanhar o olhar que vê e interpreta a cena.

Numa primeira leitura, já se percebe outro dado decisivo da perspectiva de João Cabral, pois o tema aparentemente menos poético é elevado à mesma categoria de amplitude dos demais, conquista de sua persona poética tematizada ainda num momento de procura por um dos "três mal-amados". ${ }^{16}$

Um aspecto decisivo da primeira estrofe do poema, percebido no âmbito do assunto, é que se trata do velório de um determinado morto ou melhor, "o morto" - , dado no poema com o artigo definido, o que torna o personagem estranho (não familiar), mas ao mesmo tempo identificado. Ao dizer "o morto", o Eu aproxima de algum modo esse ser do leitor, como alguém destacado, que mantém sua identidade, isto é, que de certo modo continua existindo. Para compreender melhor esses aspectos - a identidade do morto, a manutenção da vida - é preciso perceber como a estrofe está configurada e como o morto aparece qualificado. 16 Refiro-me ao discurso amoroso de Joaquim: “essas coisas de que eu desesperava por não saber
falar delas em verso” (MELO NETO, 2007b, p. 62). 
Numa primeira leitura do poema, é possível perceber com clareza certa dificuldade maior de compreensão da primeira estrofe em relação à segunda - uma maior ambiguidade - , ainda que a dificuldade não esteja no diáfano ou obscuro das imagens e da cena, antes se fazendo devido à construção sintática e outros procedimentos formais.

A dificuldade maior da primeira não está, portanto, no sentido das palavras, nem tanto em relações inusitadas entre palavras conhecidas, mas especificamente no modo de articulá-las, num sentido de circularidade que leva à repetição dos termos. É ostensivo o conjunto todo de repetições de palavras, exatamente as mesmas ou com o mesmo radical, de mesma família: "morte", "morto", "morto", "morre"; "inaugural", "inaugurar", "inaugural"; " estátua", "estátua"; "caixão", "caixão"; "meio", "meio"; "ora sua própria", "ora seu próprio". Além do que, essa repetição - pode-se dizer, retorno - é enfatizada pela proximidade sonora de outros termos: "ambiguamente", "duplamente"; "meio", "mais".

No mesmo sentido, há repetições sintáticas com termos em situação simétrica; ou mesmo frases em construção inversa, e muito truncadas. Ou ainda a repetição da pontuação, especialmente dos dois pontos, bem como das conjunções, formando polissíndetos. Por fim, a própria sonoridade também conhece repetições marcadas, criando o sentimento do retorno, do circular, como na recorrência marcada em termos chaves dos fonemas /o/ e $/ u /$. Nessa mesma direção trabalha a construção em paralelismo das frases: o desejo ou necessidade de o Eu estar sempre explicando algo que ele sabe normal, recorrente, mas que é preciso explicitar ao leitor, que o percebe estranho. Tudo isso leva a um discurso explicativo e recorrente, criando um movimento de circularidade e voltas.

A estrofe está dividida em duas partes de quatro versos cada, com a segunda reiterando a primeira, no jogo recorrente das metáforas. E cada uma das partes (quadras) formada, por sua vez, por unidades semânticas menores de dois versos, o que se mostra um traço recorrente no livro todo e na obra do autor. Nas duas partes da estrofe, a personagem está qualificada por alguns termos decisivos - "orador", "estátua" e "posse" , bem como por todo o vocabulário ligado à distinção social - "recepções", "cerimônia", "ato inaugural", "orador", "estátua", "pedestal", "posse".

Observe-se, porém, que o Eu não diz explicitamente que o morto seja um político, um bacharel ou um comendador. Não sabemos quem ele é se político, bacharel etc. - , mas podemos deduzir que pertence à elite econômica. Ou seja, aqueles qualificativos de linguagem elevada não dão a identidade precisa da personagem e criam a indefinição de sua situação profissional, num processo próprio à ambiguidade da poesia. Tais elementos são metáforas utilizadas para dar a condição social e econômica do morto na forma de um vocabulário algo requintado, sem precisar contudo sua identidade. 
Na expressão inicial "recepções de cerimônia", já está suposto que se trata de um evento marcado, sem a ideia de repetição constante, pois o plural se refere à natureza do evento, não à sua constância, o que leva a crer que mortes iguais a essa não são comuns: são poucas, e sempre um evento. O léxico relativo às condições do velório deixa isso claro: "recepções", "cerimônia", "ato inaugural", "pedestal", "dia de posse". Esse modo ambíguo ou indireto de tratar cria determinada imponência na figura do morto, que de algum modo está cercado de mistério e elevação; ou seja, se o morto é reconhecido como tal, não é familiar, nem próximo.

Assim, aquela ostensiva circularidade e os outros traços do discurso na primeira estrofe estão necessariamente ligados à condição da personagem descrita ou retratada, pois o morto está dado numa situação suntuosa, pomposa, que identificamos como decisiva no espaço representado no poema.

Todo o jogo metafórico, reiterativo, da estrofe está a serviço de uma construção circular, ligada de modo decisivo à noção de volta. O que é comum ao procedimento reiterativo da linguagem poética - a condição de circularidade ou retorno - aqui é levado ao extremo, criando a noção de um dizer que parece retornar sempre ao mesmo ponto; o sentido de volta, de entorno, dá o movimento do poema em todos os níveis nessa primeira estrofe. $\mathrm{O}$ objeto de exaltação está também ele marcado pela noção do entorno, isto é, cercado de gente por todos os lados. O "oradorestátua" - morto ilustre ou poderoso - é apreciado e exaltado por todos os lados, cercado de admiradores-bajuladores.

Assim, trata-se de um morto da elite econômica, caracterizado por um plano metafórico que o qualifica com aspectos de grupos sociais que formam essa elite, enquanto vida pública - o político, o bacharel, o comendador - , figuras recorrentes na poesia de João Cabral, tendo por trás o universo do engenho e da usina de cana-de-açúcar. Tal personagem aparece em sua poesia ora associada ao título honorífico, ora ao poder político, mas num processo em que as duas condições estão implicadas e implicam poder econômico.

O comendador, por exemplo, aparece nos poemas "Velório de um Comendador", "Comendadores jantando" e "Duas fases do jantar dos Comendadores".17 O político aparece no livro Dois parlamentos: em "Congresso no Polígono das Secas", que tem por subtítulo "ritmo senador, sotaque sulista"; e em "Festa na Casa-Grande", com o subtítulo "ritmo deputado, sotaque nordestino". ${ }^{18}$ A importância do bacharel na vida pública e, por extensão, das históricas faculdades de direito de Pernambuco aparece, por exemplo, no poema "História de mau caráter",

17 No contexto da obra de Cabral, a comenda marca antes de tudo (ou tão somente) o poder econômico do homenageado (usineiros e comerciantes).

18 Sobre esse poema - outra "festa" na poesia de João Cabral -, veja-se o ensaio de Alfredo Bosi (2004, p. 195-207). 
de Crime na calle Relator. Ao comendador, político e bacharel, liga-se um dado decisivo na poesia de Cabral: a retórica pretensiosa, pomposa, vazia, literalmente bacharelesca, que marcou de modo decisivo a vida social e mental do País, e sempre esteve acompanhada da exploração do homem iletrado, como dão testemunho as obras de Lima Barreto, no espaço urbano, e de Graciliano Ramos, no espaço rural.

O movimento circular da exaltação a que nos referimos, do elevado da linguagem, parece contaminar já o início do poema, com a expressão quase repetitiva e pluralizada do primeiro substantivo; ou seja, a configuração dessa linguagem está discretamente parodiada logo de saída no poema, na expressão "recepções de cerimônia". A repetição de termos quase idênticos ecoa parodicamente a pomposidade da ocasião no plano sonoro, com o plural culto da palavra "recepções". A terminação com o plural em /ões / repete aquela relação esférica, de volta, de torneio, que está em toda a primeira estrofe. De algum modo, a palavra inicial, com sua terminação, eleva a pronúncia, dando o caráter ostentatório da expressão, e fazendo ecoar outros termos igualmente pomposos: "barões", "brasões", "casarões"; ou seja, o poema se abre de maneira bastante cerimoniosa.

Para mencionar um caso análogo ao de Cabral, ocorre fato semelhante no poema "Procura da poesia", de Carlos Drummond de Andrade: o poeta muda o registro verbal para dar essa dimensão suntuosa (e irônica) da matéria, de que falamos:

\author{
Não te aborreças. \\ Teu iate de marfim, teu sapato de diamante, \\ vossas mazurcas e abusões, vossos esqueletos de família \\ desaparecem na curva do tempo, é algo imprestável.19
}

Percebe-se que o poeta alterou o pronome de "teu" para "vossas" e "vossos" sem justificativa aparente, e preferiu "abusões" a "crendices", por exemplo, para esse mesmo efeito ostentatório e vazio, que se completa com as sugestões ligadas aos demais elementos do excerto.

O dado fundamental desse procedimento, como foi dito, é que ele se faz ironicamente. A retórica está ironizada tanto no léxico quanto na construção sintática, através da paródia e negação que vem da exageração do procedimento. Alfredo Bosi (2000, p. 198-9) chama atenção para isso ao tratar da poesia do autor - especialmente do poema "Comendadores jantando" - , definindo o procedimento como "retórica da intensidade", o que busca criar um desacerto entre discurso e matéria, desfazendo a "associação entre estilo e tema, rebaixando este e potencializando livremente aquele".

O vínculo de Cabral a esse estilo ou procedimento é amplo e reiterado pelo autor em mais de uma entrevista: numa delas, ao responder

19 "Procura da poesia", in A rosa do povo. 
sobre o que gostaria de ver mais tratado pela crítica em sua obra, chama atenção para o lado do humor negro de sua poesia (MELO NETO, 1996, p. 27). ${ }^{20}$ Humor negro, paródia, sátira são termos afins que frequentam sua poesia, especialmente a partir da tematização da miséria em um contexto de contrastes aberrantes, numa atitude que implica afastamento e frieza, mas não deixa de trair uma emoção subterrânea. E a força do procedimento satírico para o poeta - visto num de seus autores de eleição, Jonathan Swift - aparece claramente nos versos que dedicou a este:
ouvir os planos-afinal para os Yahoos com um sorriso na boca engatilhado: na boca que não pode balas, mas pode um sorriso de zombaria, tiro claro. ${ }^{21}$

E alguns versos de outro poema dedicado ao mesmo autor poderiam ser tomados como comentário à estrofe do poema que estamos lendo, com a qual guarda certa semelhança na construção:

Para falar dos Yahoos, se necessita
que as palavras se rearmem de gume,
como numa sátira; ou como na ironia,
se armem ambiguamente de dois gumes. ${ }^{22}$

Dessa forma, sua obra será marcada por esse traço irônico e satírico, sempre procurando denunciar a fraude que possa se esconder no discurso retórico a serviço de uma classe. No poema "Graciliano Ramos:", ao lado de apontar o rigor da escrita do autor alagoano - tema caro ao poeta - , Cabral fala também da intenção em escapar ao lado perverso da linguagem, sua dimensão de ideologia:

Falo somente do que falo: do seco e de suas paisagens, Nordestes, debaixo de um sol ali do mais quente vinagre:

que reduz tudo ao espinhaço, cresta o simplesmente folhagem, folha prolixa, folharada, onde possa esconder-se a fraude. ${ }^{23}$

\footnotetext{
${ }^{20}$ Também na conferência de 1954, o poeta lamenta que a própria poesia moderna, segundo ele, tenha abandonado a exploração da poesia satírica (MELO NETO, 1998, p. 100). Ainda que de passagem, a crítica se voltou para essa questão em sua obra, como é prova a citação de Alfredo Bosi, bem como considerações, por exemplo, de Benedito Nunes (2007, p. 81 e 121-3) ou Félix de Athayde (2000, p. 83-6), e outros certamente.

21 "The Country of the Houyhnhnms", in A educação pela pedra.

22 "The Country of the Houyhnhnms (outra composição)", op. cit.

${ }_{23}$ "Graciliano Ramos:", in Serial.
} 
Voltando ao poema, a estrofe exalta o morto, à medida que caminha em torno dele o tempo todo; exaltar, literalmente, tem o sentido de elevar, engrandecer, tornar alto. Para isso, é preciso voltar o tempo todo ao mesmo e único objeto do discurso, caminhando em torno dele; a exaltação é um dizer cheio de volteios. Se a linguagem da canção - a lírica mais intensa - é um discurso que gira e gravita em torno de um centro secreto (KAYSER, 1985, p. 380-1), no poema que estamos lendo o morto é uma espécie de centro vazio cercado por todos os lados de pessoas e discursos. A estrofe exalta o morto ironicamente, não desfazendo de suas qualidades de modo agressivamente satírico, como ocorre em outros momentos da obra do autor. A sintaxe e as metáforas falam da condição ostentatória, que se faz com um discurso elevado, numa linguagem ordenada e "argumentativa", cuja recorrência explicativa cria o efeito da exageração irônica. Assim, o movimento do dizer do poema é marcado por esse girar em torno de, que eleva a figura, sem propriamente exaltá-la ou, então, exaltando-a ironicamente.

No tom da estrofe, há uma gravidade que não é enfática, nem pesada, mas que dá aos versos certa solenidade exagerada. Se não é agressivamente satírico (a compostura do discurso já faz parte da paródia), há um motivo para isso; ou seja, há um motivo para essa ironia discreta do Eu que, mais do que ironizar, parece apenas registrar; a sátira (num tom mais ácido) quebraria a unidade tonal próxima da revelação trágica, que virá ao final do poema.

Mas mesmo com esse constante retorno e circularidade do discurso (de pouquíssimos verbos), é preciso notar que a estrofe não termina como começou: o dizer circular caminhou e modificou o poema desde o seu início, como é próprio do dizer poético. ${ }^{24}$ Do ponto de vista das metáforas (das imagens), o "morto" se transforma em "estátua", em pedra portanto, em objeto, em coisa. Esse fato é o final de um processo de desumanização, pois um dado fundamental da ironia da estrofe é a ausência de qualquer traço de vida privada. $\mathrm{O} E u$ não faz qualquer referência a relações sentimentais ou afetivas nessa primeira estrofe. Essa ausência de laços afetivos desumaniza a morte propositalmente, mostrando que o que importa ao Eu é o caráter diretamente público da figura. Importa o que socialmente, enquanto relação de classe, significa aquela figura, e não a morte enquanto conflito existencial.

As imagens centrais do morto possuem um movimento inverso, da primeira para a segunda parte da estrofe: na primeira parte, a ordem da aparição é: "morto", "orador", "estátua"; mas na segunda, será: "morto", "estátua", "orador" ("em dia de posse"). Há uma composição clara na estrofe, que começa falando do "morto" e termina falando de "seu próprio

${ }^{24}$ Refiro-me à definição de função poética de Roman Jakobson (1969, p. 127 e ss.), em que as equivalências do discurso (formando a circularidade) ampliam o sentido na forma de uma sequência; nesse sentido, ver também Alfredo Bosi (2000, p. 34 e ss.), que desenvolve a questão. 
vivo, em dia de posse", criando uma sugestão de agitação e vida. Primeiro, fala de "morte"; depois, em "ato inaugural"; e finalmente, "em dia de posse". A ironia está em que o morto caminha da morte para a vida, com a inauguração do seu cadáver-estátua. Ou seja, onde havia morte, há inauguração e posse (colocada em destaque na rima final), implicando recomeço e propriedade; imagens que falam, de algum modo, de renascimento e, certamente, de continuidade.

A estátua, a inauguração e a posse implicam a permanência do morto, pela manutenção do poder, que lhe dá direito à memória. A estátua está ligada à adoração e ao endeusamento (na origem, imagem da divindade) que busca superar a morte. O morto preserva sua identidade pelo poder e pela memória, o que é uma maneira de vencer a morte - a noção de posse está ligada à de poder. Mesmo porque deve-se atentar para o fato de que "seu próprio vivo" sugere a continuidade do nome e dos bens de família através do filho - aqui também a relação etimológica entre próprio e propriedade; e não passa despercebida a paronomásia virtual entre seu próprio vivo / seu próprio filho, o que liga intrínseca e contraditoriamente a primeira estrofe à segunda, como veremos. ${ }^{25}$ Assim, já dentro dessa primeira estrofe percebe-se o sentido irônico da inversão - um morto que vira estátua, faz discurso e toma posse - , fazendo com que a morte seja realmente uma festa e continuação da vida.

Antes de entrar na segunda estrofe do poema (na segunda "festa"), é preciso trazer à conversa o ensaio de Antonio Candido que deu ensejo a esta leitura - "A passagem do dois ao três" - , do qual pretendo extrair um aspecto central para dar direção à leitura do restante do poema (considerando também o que já foi lido). Como se sabe, o ensaio nasceu de uma discussão de Candido acerca do estruturalismo e sua vocação para as formulações binárias (deixo de lado, por não interessar para a presente leitura, a situação particular que deu origem ao ensaio, a leitura de Affonso Romano de Sant'Anna sobre O cortiço, de Aluísio Azevedo). ${ }^{26}$

O ponto central, que mais interessa neste momento, é o fato de que ao mencionar algumas dualidades formuladas pelo estruturalismo, $\mathrm{o}$ crítico sente a necessidade de criar um terceiro termo que desse um

\footnotetext{
${ }^{25} \mathrm{~A}$ ambiguidade é sugerida pelo fato de que "próprio" enquanto substantivo significa, conforme o dicionário Aurélio, "portador ou mensageiro" e, por extensão, representante; certamente o filho e herdeiro se encarregaria do discurso de louvor e, posteriormente, de posse.

26 "A passagem do dois ao três (Contribuição para o estudo das mediações na análise literária)" foi publicado originalmente na Revista de História da Universidade de São Paulo, n. 100, 1974. No livro Textos de intervenção (2002), o ensaio aparece como parte de uma montagem feita pelo organizador Vinicius Dantas - "Duas vezes 'A passagem do dois ao três'" - do ensaio em questão com o ensaio "Literatura-Sociologia"; na nota do organizador, bem como na nota do próprio autor ao ensaio "De cortiço a cortiço" em O discurso e a cidade, está explicada a gênese e trajetória das publicações.
} 
movimento dialético ao que, de outra forma, poderia ser apenas contrastante. Ao ler brevemente (nesse ensaio) o romance de Aluísio e suas oposições tratadas enquanto dualidades pelo estruturalismo - Natureza x Cultura, Cortiço x Sobrado - , Candido propõe um terceiro elemento (o Trabalho) que faria a mediação entre elas, dando um sentido mais complexo às oposições, muitas vezes fazendo-as trocar de sinal, quando, em princípio, seriam vistas como estanques ou redutoras. Como diz o crítico: "Entre Natureza e Cultura se interpõe, portanto, a Sociedade, marcada pela luta de classes, em torno da apropriação dos meios de produção". E logo a seguir: "Entre o Cru e o Cozido [categorias paradigmáticas à época], avultam os meios segundo os quais é possível cozer os alimentos e determinar como e por quem serão consumidos" (CANDIDO, 2002, p. 66-7).

Candido vê então duas maneiras possíveis de abordar uma obra literária, uma partindo de fora para dentro, dos dados externos para uma análise formal; outra, de dentro para fora, da análise formal para a compreensão das implicações sociais do texto (p. 68). ${ }^{27}$ Num caso e noutro, o crítico supõe a obra como uma "estrutura de relações e tensões vista do ângulo dos elementos mediadores" (p. 67). Dessa forma, com a passagem do dois ao três, a obra pode ser vista num processo integrativo de leitura - estrutural, não estruturalista - , em que ela aparece como expressão viva do espaço social em que nasceu. O trabalho (elemento social e externo) passa a interno, se considerado de algum modo como parte da estrutura da obra.

Voltando ao poema de Cabral, a leitura da segunda estrofe poderia ser vista, em princípio, como o avesso da primeira num procedimento de leitura que considerasse somente o binarismo da construção; entretanto, é possível aproximá-las mais intrinsecamente, vendo que externamente (e internamente também, pelas implicações sugestivas da linguagem poética) uma nasce da outra, uma só existe em função da outra. Vejamos como isso pode se dar.

Poderíamos dizer que enquanto a primeira estrofe caminhava circularmente, a segunda o fará em linhas paralelas; se a sintaxe da primeira estrofe era feita de círculos e volteios, a segunda - para falar com

\footnotetext{
${ }^{27}$ Como sabe o leitor do texto, Candido fará uma leitura do romance de Aluísio a partir de um dito preconceituoso contemporâneo à obra (o dito dos três pês), que o crítico analisa detalhadamente para mostrar a mentalidade rasteira que está na base da vida social de onde partiu o romance: "Para português, negro e burro, três pês: pão para comer, pano para vestir, pau para trabalhar" (p. 68). Cito esse caso por uma coincidência com João Cabral: o poeta vai criar também um dito na língua dos pês, mas para desvendar criticamente a realidade cruel de onde nasce, como faz a análise de Candido: "O negro da cabra é o negro/ do preto, do pobre, do pouco." ("Poema(s) da cabra”, in Quaderna).
} 
Álvaro de Campos - será um poema em linha reta. Mas dizendo dessa forma, seria ficar no reconhecimento formal de um desenho sintático que ganha sentido à medida que um terceiro elemento ligue suas linhas; se ficássemos somente no diagrama sintático - a circularidade de um lado, a linearidade de outro - , isso nos daria apenas um contraste, sem se alçar à contradição; para dar esse salto, é preciso daquele terceiro elemento - a morte. Dessa forma, compreenderemos também o procedimento estratégico do estranhamento como "expediente deslegitimador em todos os níveis, político, social, religioso" (GINZBURG, 2001, p. 33).

O primeiro ponto a observar, portanto, é que não se trata aqui da mediação estabelecida pelo ensaio de Antonio Candido, ao comentar o romance de Aluísio Azevedo. Ou seja, não se fala do trabalho explicitamente em momento algum do poema; seu tema é a morte, dada já no título, ali transformada de algum modo em festa. Sendo assim, o terceiro elemento do qual devemos lançar mão é a morte, não o trabalho, pois ele, como foi dito, não aparece. Mas aqui já podemos antecipar dois aspectos que virão mais tarde: a) se o trabalho não aparece, é preciso ver por que não aparece; b) o mais decisivo: a morte não se desvincula do trabalho. Vejamos então como a segunda estrofe se configura enquanto avesso da primeira.

A passagem de uma estrofe a outra, em qualquer poema, supõe sempre um desdobramento temático que ganha em ser visto como mudança em relação à estrofe anterior; no caso de nosso objeto, isso é ainda mais significativo pela própria construção do poema (e do livro em que se insere). O desejo de dar o avesso da primeira está já na construção de equivalência entre as duas estrofes, formadas ambas por duas quadras, dentro da obsessão cabralina pelo quaternário, e pelo próprio número quatro.

Antes de entrar nessa segunda estrofe, é preciso considerar o modo formal como estão interligadas. No livro A educação pela pedra, há duas maneiras básicas de criar um vínculo formal entre as estrofes: o número 2, que aparece numa grande série de poemas; e um sinal gráfico - asterisco ou um outro que faça as vezes dele, conforme o critério de edição. Quanto ao número 2, não parece haver dúvida: trata-se de um desdobramento continuado entre a primeira e segunda partes; um caso conhecido é o do poema "Tecendo a manhã": na primeira estrofe, os galos cruzam os fios de sol propiciando o despontar da manhã; na segunda, já com a luz intensa, ergue-se a tenda-toldo que cobre a todos. Mas no caso do asterisco, o sentido é outro: implica de algum modo a negatividade e, num caso como este que estamos lendo, implica propriamente a contradição, em que uma cena social aparece vinculada pelos dados de identificação com a outra, ao mesmo tempo mostrando a impossibilidade de qualquer convivência.

Como os elementos que compõem a segunda estrofe se articulam com a primeira? O tema da segunda estrofe continua sendo a morte, 
tratada como festa, mas agora dada num outro contexto: não mais o velório de um único morto, reconhecido e celebrado, mas sim a multiplicidade de mortos sem rosto - "os enterros de criança no Nordeste".

A estrofe se abre, criando uma simetria com a abertura da primeira, em chave irônica: se lá a morte dava "recepções de cerimônia", aqui ela se transforma na leveza (hedionda) dos "piqueniques infantis", em brincadeira de criança; se lá havia a noção de algo estranho ou suntuoso, ligado ao inusitado, àquilo que precisa ser dado a conhecer, aqui há a noção do rotineiro, do sabido, de algo que é dado como espetáculo monótono e automatizado e que, por isso mesmo, precisa ser reconhecido. E nem falta a simetria da tensão no plano da sonoridade, pois se lá a circularidade do discurso e sua imponência encontravam eco na sonoridade redonda do /o/ e dos /ões/, agora o "alarido" das crianças encontra eco na assonância estridente dos /i/s, amparados pela sonoridade também estridente das oclusivas $/ p /, / q /, / t / \mathrm{e} / d /$, bem como na recorrência das sibilantes em vários termos chaves.

Entretanto, o segundo verso estabelece uma quebra violenta no discurso, ao dizer objetivamente de que piqueniques e mortes se trata; ao dizer "os enterros de criança no Nordeste", a frase muda decisivamente o registro de antes: se lá o discurso tinha a circularidade da exaltação, agora as frases ganham um sentido retilíneo, formando orações coordenadas ou de uma sintaxe extremamente simples - em ordem direta, sem repetições, inversões, ou mesmo ambiguidades sintáticas. Isso se deve não só à coerência interna com o objeto representado (criança, infância, pobreza), mas sobretudo porque essa objetividade na representação, dizendo direta e explicitamente a cena vista, com uma linguagem quase jornalística, dá ao verso um tom de denúncia pela iniquidade que se apresenta.

Tal iniquidade é responsável por outras oposições óbvias, que poderiam dispensar o registro: a) entre "um morto" com sugestão de aspecto jovial (a jovialidade, beleza e cuidados físicos de quem vai tomar posse num cargo ou ser homenageado), ainda assim sem morrer fora de idade, e a morte "de criança"; b) entre o velório no primeiro caso, pomposo, e "os enterros" sem ritual nenhum vindo dos adultos (o "piquenique" é, antes, uma cena macabra). Diferente da primeira, portanto, em que os versos se enredam, se enroscam, nessa segunda estrofe cada verso vale por si, num procedimento acumulativo: são diretos e cada um tem o tom de uma nova denúncia. Isso dá um ritmo mais acelerado à estrofe e, portanto, mais dramático, pois caminha de maneira mais rápida para o final.

As imagens orgânicas começam por um ponto fundamental, a necessidade do brinquedo para a criança. Sendo assim, todas elas saem de uma alegoria do que seria a vida normal e saudável de uma criança no seu desenvolvimento intelectual e afetivo, que é feito, certamente, de restrições como, por exemplo, o conhecimento da morte. Nesse sentido, o poema subverte os opostos, pois a brincadeira é feita justamente com a morte. 
Assim, o primeiro e os demais versos falarão ironicamente - com imagens de uma unidade cerrada - de uma realidade que foi suprimida da vida das crianças-personagens, transformando o que deveria ser aquele desenvolvimento emocional e intelectual num teatro grotesco.

Logo no terceiro verso, ao dizer que tais piqueniques são "reservados a menores de treze anos", mostra qual a expectativa de vida das personagens infantis, chamando atenção para o número aziago; entretanto, os "piqueniques" são "reservados" a todos os menores de treze anos, não a um só, o que redireciona o agourento: é assim não por terem a idade malfadada, mas por terem nascido em condições malfadadas. $\mathrm{Na}$ verdade, a referência à idade das crianças faz lembrar o início de Morte e vida severina, em que o retirante explica que todos estão sujeitos à "mesma morte severina":

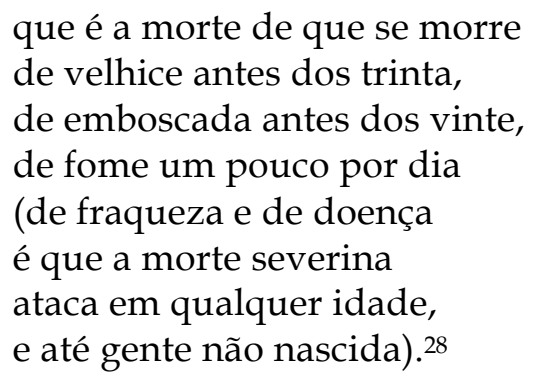

E o verso seguinte completa esse sentido ao dizer que tais piqueniques são "impróprios a adultos (nem o seguem)", o que fala daquelas restrições que supõem um desenvolvimento normal da vida infantil (pois são impróprios a adultos); a ironia está não somente no fato de as crianças não chegarem a adultos, mas também invertendo o discurso esperado, pois se é impróprio, deveria sê-lo justamente para as crianças. E o verso aponta para a rotinização dos enterros, pois os adultos "nem o seguem" - expressão do descaso reificado que trai uma curva tonal no poema, mostrando discretamente a presença emocional do Eu.

Retomando nesse passo a construção ambígua da estrofe anterior, a segunda quadra se abre com a duplicidade irônica ("meio/meio") que instaura as últimas metáforas: "Festa meio excursão meio piquenique", que se dá "ao ar livre" e é "boa para dia sem classe". A ironia da primeira expressão não está só no choque entre o saudável do ar livre e o funéreo da situação: está antes na própria configuração social do "ar livre", que marca o indefinido do limite entre vida e morte. É expressão que traz à memória a configuração de um dos "cemitérios pernambucanos" de Cabral:

\footnotetext{
${ }^{28}$ Esses versos e o do poema em análise fazem lembrar o mencionado depoimento de Cabral (cf. nota 9), em que o poeta conta que resolveu escrever $O$ cão sem plumas quando leu certa matéria sobre a expectativa de vida no Nordeste.
} 
Mortos ao ar-livre, que eram,

hoje à terra-livre estão.

São tão da terra que a terra

nem sente sua intrusão. ${ }^{29}$

A segunda expressão do verso possui uma ironia ostensiva, completando a primeira: "boa para dia sem classe". No plano metafórico, trata-se também aqui do estranhamento feito a partir de uma situação diametralmente oposta, pois são crianças que nunca souberam o que é escola; mas a escolha metonímica do poeta (classe ao invés de escola) não passa despercebida, pois as crianças são filhas de uma população que está abaixo de qualquer definição econômica. ${ }^{30}$

Os dois últimos versos completam e trazem a imagem reveladora do horror da situação: "nela, as crianças brincam de boneca/ e, aliás, uma boneca de verdade". É no último verso - preparado pelo anterior, mas cuja força depende do modo todo como as imagens se organizam - que aparece a imagem horrenda, antecedida por uma variação tonal (a maior do poema e discreta como queria Cabral) com a presença do advérbio "aliás", indicando um dado casual que poderia passar sem ser notado. $\mathrm{O}$ advérbio e a tonalidade discretamente alterada antecedem a imagem grotesca e chocante do final, dada na construção perifrástica "boneca de verdade", que ilumina com a claridade tônica do $/ a /$ a realidade sinistra.

A perífrase "boneca de verdade" aparece também como se fosse uma orientação ao leitor (e ao próprio Eu), que não conhece esse brinquedo; imagem que se torna mais cruel também pelo detalhe de estar associada à menina (e à boneca). Somente agora aparece a menção particularizada à criança morta, ou seja, só agora aparece a personagem do enterro; somente agora ela entra em cena, diferente da situação anterior, em que o "morto" estava o tempo todo presente. E não passa despercebida a contiguidade irônica com o final da primeira estrofe: num caso, a sugestão do filho que continua a propriedade do pai; no outro, a geração de filhos que nascem mortos.

Nesta parte do poema, aparece de maneira mais contundente também o tratamento satírico que o autor empreende, agora com mudança evidente de tom em relação à primeira. Na primeira estrofe, a frieza da sátira implicava um afastamento que se traduzia numa espécie de descrição neutra do evento, mas que, como foi dito, supunha

\footnotetext{
29 "Cemitério pernambucano (Nossa Senhora da Luz)", in Paisagens com figuras.

${ }^{30}$ Não resisto nesta passagem a comentar pontualmente uns versos ao final de Morte e vida severina (1956): quando nasce a criança - que numa leitura alegórica poderia ser vista como o renascimento do mito cristão - , duas "ciganas do Egito" vêm predizer a sorte futura do menino: a primeira o descreve preso ao lugar, reproduzindo a condição paterna; a segunda, entretanto, o descreve vendo nele não a mancha de lama, mas da "graxa de sua máquina", na condição de "homem de ofício", cuja vida tem também "precipícios" (MELO NETO, 2007a, p. 129). Neste caso, a criança passará de "sem classe" à classe operária, e a mudança do processo histórico não será pequena, nem para ela, nem para o País.
} 
discretamente uma exageração que rebaixava a cena, materializada no discurso parodiado e nas imagens que subvertiam o sentido da cerimônia.

Nesta segunda estrofe, o satírico supõe uma tomada de posição por parte do Eu que observa a cena, ainda que dentro do afastamento que evita o sentimentalismo; mas a alteração discreta da entoação, o caráter de denúncia, o desnudamento final da imagem mostram que o satírico se aproxima aqui de uma intensidade ao mesmo tempo mais cruel e trágica. A crueldade, como vimos, foi aprendida com a prosa de Swift - e não resta dúvida de que a cena representada corresponde à modesta proposta do poeta brasileiro diante da fome infantil. Curiosamente, além do sacrifício das crianças, o "aprimoramento" do projeto do irlandês se faria com o sacrifício dos "Rapazes e Moças, de não mais de quatorze Anos nem menos de doze" (SWIFT, 1993, p. 15). Mas é certo também que o tom se distingue entre as duas obras, pois o poema é coerente com a alegoria criada do brinquedo infantil, o que dá ele uma tonalidade de lirismo frágil e trágico. ${ }^{31}$

A expressão "de verdade" parece referir-se ao todo do poema ironicamente, como sendo esta a única e verdadeira realidade (que pode passar despercebida como um detalhe) diante do teatro grotesco e trágico encenado pelas estrofes. $\mathrm{O}$ "de verdade" não é só a imagem horrenda do cadáver, mas expressão da realidade revelada pela poesia, o discurso que desmascara a retórica da primeira estrofe; para falar com o poema sobre Graciliano, a segunda estrofe é a prova da fraude que se escondia no discurso da primeira. $\mathrm{Na}$ verdade, com a expressão final rompe-se a alegoria, e a realidade aparece "como o sol sobre o olho", que bate nas pálpebras "como se bate numa porta a socos". ${ }^{32}$

\section{De pedras e homens}

Retomando o ensaio de Antonio Candido, proposto no início da leitura, podemos aproximar ainda mais as duas estrofes-festas do poema, pois o processo histórico implicado na primeira estrofe é o mesmo da segunda, e responsável pela violenta oposição. As duas estão tematizando a morte, não como um ato natural e, sim, como um ato da vida social, decidido pelas condições de classe. Na primeira, a Natureza parece ser vencida pela capacidade do morto (e suas posses) de superar a morte com a manutenção da memória e de tudo que fez sua fortuna na Terra; na segunda, o "arbitrário" da Natureza cai com todo seu peso, sem encontrar resistência alguma na situação de desamparo e fragilidade das personagens envolvidas. Vendo melhor agora, podemos dizer que o tema do poema não é a morte: o tema de fato do poema é o modo como se morre.

\footnotetext{
31 Sobre o assunto, diz Frye (2013, p. 370): “A ironia com pouca sátira é o resíduo não heroico da tragédia". Nesse sentido, a ironia do poema começa próximo da sátira e vai se aproximando da tragédia.

32 “Graciliano Ramos:", in Serial.
} 
Não há no poema qualquer menção à condição existencial implicada na morte, sendo antes tratada enquanto uma condição de classe. Nesse sentido, o poema inverte o senso comum, pois a morte não iguala nada: apenas reforça as diferenças que havia.

E isso leva a uma questão central da condição histórica das personagens envolvidas no poema: note-se que na primeira estrofe não há referência de lugar do morto ilustre que protagoniza a cena; na segunda, ao contrário, o lugar está definido: o Nordeste pobre. No primeiro caso, podemos entender por duas vias: a primeira, que não está definido porque o morto ilustre pertence à elite brasileira, independente da região de origem, o que leva à consideração de que não há diferença entre as regiões nesse caso; de fato, o morto pode ser do Nordeste ou de qualquer outra região, pois a elite morre do mesmo jeito em qualquer lugar, ou seja, morre bem em qualquer lugar; os pobres é que morrem mal de diferentes maneiras. Sendo assim, dado o caráter universal da elite, não há porque restringi-la. Mas a representação da tragédia da segunda parte do poema pode também ser lida como uma história que se amplia para todo o País, pois a particularização da pobreza implica também a coexistência de outras particularidades, bastando observar o modo como a miséria se materializa em cada caso - e não seria difícil apontar a violência contra a infância por espaços: à lembrança do leitor ocorrem na hora as mortes (de crianças pobres) por "bala perdida" no Rio, só para ficar num exemplo.

Mas a outra via é pensarmos o morto do poema como pertencente à elite pernambucana, em especial, como ficou dito na análise da estrofe, que frequenta a obra de João Cabral e sofre o retrato satírico de sua pena. Há claramente uma definição desse morto ilustre, se tomarmos sua obra e as personagens da elite que a frequentam. Não é difícil definir três figuras dessa classe: o senhor de engenho / usineiro; os políticos; os bacharéis. Não importa quem seja o morto ilustre, pois ele pertence a um desses três segmentos: na verdade, o bacharel é filho do político que, por sua vez, é filho do senhor de engenho; sendo assim, se um está morto, o outro faz o discurso de exaltação e posse (dele e do pai), e a propriedade segue sem acidentes.

Quando incorpora o "tema social" à sua poesia, o poeta direcionará seu olhar para o Nordeste pobre, detendo-se em três bolsões de miséria: o ribeirinho da zona litorânea, mergulhado no lodaçal do mangue; o cassaco de engenho ou de usina, sofrendo a "foice da cana"; por fim, o retirante do semiárido, que busca na sua errância o que comer. Assim, "do lado de fora" estão os pobres, que também trocam de lugar: o cassaco de engenho, $\mathrm{o}$ retirante, o ribeirinho, todos bastante tematizados na obra de Cabral. $\mathrm{O}$ primeiro trabalhou para o avô (as crianças do poema são ainda filhas da escravidão), e as consequências desse trabalho estão nas estrofes memoráveis de Dois parlamentos e do poema $O$ rio; se não sucumbiram à usina, sucumbiram à seca (flagelo natural contra os pobres), e parece ser o 
caso dos pais das crianças; se tentam escapar e fogem para o litoral, sobralhes o lamaçal pestilento do rio, onde se transformam (homem e rio) no cão sem plumas. Entre os dois extremos do poema, o leitor pode sentir falta da classe média, mas ela está lá certamente: não nos "piqueniques" das crianças (estas estão só), mas na primeira festa, pois o discurso (pura ideologia) supõe um destinatário; e a própria condição pública do velório é um convite para que ela vá beijar a mão do morto.

$* * *$

Por fim, gostaria de me deter um pouco na ausência dos pais das crianças do poema em questão (presentes em outro poema) para tratar ainda desse movimento dialético propiciado pelo ensaio de Antonio Candido. Tomo, para isso, o poema que dá nome ao livro, e que comentarei em poucos parágrafos, a fim de perceber o alcance extraordinário da formulação crítica do ensaio de Candido. Faço um comentário geral sobre o poema, sem me deter em aspectos particulares da forma, apenas apontando uma direção de sentido para as imagens.
A educação pela pedra
Uma educação pela pedra: por lições; para aprender da pedra, frequentá-la; captar sua voz inenfática, impessoal (pela de dicção ela começa as aulas). A lição de moral, sua resistência fria ao que flui e a fluir, a ser maleada; a de poética, sua carnadura concreta; a de economia, seu adensar-se compacta: lições da pedra (de fora para dentro, cartilha muda), para quem soletrá-la.
*
Outra educação pela pedra: no Sertão (de dentro para fora, e pré-didática). No Sertão a pedra não sabe lecionar, e, se lecionasse, não ensinaria nada; lá não se aprende a pedra: lá a pedra, uma pedra de nascença, entranha a alma.

Como todos do livro, o poema é composto também por duas estrofes: na primeira, estão as lições que formam a educação ministrada pela pedra: a lição de dicção, de moral, de poética, de economia, todas essas lições visceralmente cabralinas, já que estão dadas numa "cartilha muda". E não há porque de antemão negar essas lições, salvo, é claro, pelas escolhas que cabe a cada um, mas não porque elas sejam um equívoco em 
si. São lições "universais", pois não estão determinadas por nenhum contexto específico, tanto que os verbos ligados ao aprendizado do leitoraluno estão no infinitivo: "para aprender", "frequentar", "captar", "soletrar". São lições contraditórias como outras quaisquer, mesmo que tragam consigo aquela certeza própria do lírico, que não apresenta argumentos para falar de sua verdade. Como foi dito, o leitor pode aceitar ou recusar tais lições, mas este é ponto: imitar a pedra é um ato humano, porque a imitação é um ato humano e que humaniza o homem. É tão humana a imitação da pedra quanto a imitação da rosa. Outra coisa bem diversa é a petrificação dos homens, e é sobre isso que falará a segunda estrofe.

Na segunda estrofe do poema, também separada pelo asterisco da contradição, as coisas mudam de figura - a "outra" educação é algo bem diferente da primeira -; e a perspectiva da voz lírica mantém-se com o mesmo distanciamento do outro poema. De fato, ocorre aqui, como no poema anterior, uma mudança fundamental entre as estrofes: a pedra aparece num contexto particularizado, situada historicamente na vida do homem brutalizado do Nordeste pobre. Nele, a pedra "entranha a alma", e não tem nada a ensinar, o que joga por terra os belos ensinamentos anteriores, pois "lá não se aprende a pedra", o que seria ainda um ato humano. E nem se pense que o poeta vê sempre a imagem da pedra de forma fixa, sem o movimento que torna os seres vivos: no poema "O vento no canavial", por exemplo, ele fala das "estrelas" formadas pela multidão "lutando na praça cheia", estrelas que são belas pois "é solta sua simetria", diferente das pedras, que têm "disciplina de milícias". ${ }^{33}$

Mas a pedra não desumaniza o homem: como pode então habitar a alma do sertanejo? Talvez não se esteja falando de pedra. O impasse se resolve se entendermos que a pedra na segunda estrofe é o símbolo que concentra as mediações sociais que brutalizam o homem pobre, sua exploração no trabalho; a pedra da segunda estrofe é o trabalho. Assim como no outro poema a morte não era um fato de Natureza e, sim, de Sociedade (continuo com os termos de Candido no ensaio), aqui a pedra é também ela um fato de Sociedade e, não, de Natureza; a pedra não desumaniza ninguém: quem desumaniza o homem é o próprio homem. Sendo assim, ela cumpre aqui a mesma mediação que cumpre a morte no outro poema; ou seja, ela concentra o destino que está reservado ao sertanejo desde sempre, como no outro poema o destino da criança já estava "reservado" para ela desde o início.

Assim, ela cumpre o papel da morte no poema anterior, ligando negativamente as duas estrofes; da mesma forma que por trás da morte da criança, no outro poema, estão as condições de trabalho a que os pais estão sujeitos. $\mathrm{O}$ trabalho, que não aparecia no outro, aparece agora como

33 "O vento no canavial", in Paisagens com figuras. 
expressão da violência na vida social brasileira, violência que se completa ao transformar a morte numa brincadeira. Desse modo, se a pedra ainda tem alguma lição a ensinar, com a negatividade dos dois poemas, a lição é uma só: que os homens morrem como trabalharam. 


\section{Referências bibliográficas}

ATHAYDE, Félix de (comp.). Ideias fixas de João Cabral de Melo Neto. Rio de Janeiro: Nova fronteira; São Paulo: UMC, 1998.

ATHAYDE, Félix de. A viagem ou Itinerário intelectual que fez João Cabral de Melo Neto do racionalismo ao materialismo dialético. Rio de Janeiro: Nova fronteira; Fundação Biblioteca Nacional, 2000.

BOSI, Alfredo. "Fora sem dentro? Em torno de um poema de João Cabral de Melo Neto". Estudos Avançados. São Paulo, v. 18, n. 50, jan./ abr. 2004.

BOSI, Alfredo. "Imagem, discurso" e "Poesia resistência". O ser e o tempo da poesia. São Paulo: Companhia das letras, 2000 (6 $\left.{ }^{\mathrm{a}} \mathrm{ed}\right)$.

MELO NETO, João Cabral de. "Da função moderna da poesia”. Prosa. Rio de Janeiro: Nova fronteira, 1998.

MELO NETO, João Cabral de. A educação pela pedra e outros poemas. Rio de Janeiro: Alfaguara, 2008a.

MELO NETO, João Cabral de. A escola das facas /Auto do frade. Rio de Janeiro: Alfaguara, 2008b.

MELO NETO, João Cabral de. Agrestes. Rio de Janeiro: Alfaguara, 2009a.

MELO NETO, João Cabral de. Crime na calle Relator / Sevilha andando. Rio de Janeiro: Alfaguara, 2011.

MELO NETO, João Cabral de. Entrevista. Cadernos de Literatura Brasileira 1. São Paulo: Instituto Moreira Salles, 1996.

MELO NETO, João Cabral de. Morte e vida severina e outros poemas. Rio de Janeiro: Alfaguara, 2007a.

MELO NETO, João Cabral de. Museu de tudo. Rio de Janeiro: Alfaguara, 2009b.

MELO NETO, João Cabral de. O cão sem plumas e outros poemas. Rio de Janeiro: Alfaguara, 2007b.

MELO NETO, João Cabral de. O cão sem plumas. Fotografias Maureen Bisilliat. Rio de Janeiro: Nova fronteira, 1984.

CANDIDO, Antonio. "Candido comenta texto em que fez a descoberta de Cabral". Folha de S. Paulo. São Paulo, 11 out. 1999 (Caderno Especial).

CANDIDO, Antonio. "De cortiço a cortiço" e "Nota sobre os ensaios". O discurso e a cidade. São Paulo: Duas cidades, 1993.

CANDIDO, Antonio. "Duas vezes 'A passagem do dois ao três" e "Poesia ao Norte". Textos de intervenção. Seleção, apresentações e notas Vinicius Dantas. São Paulo: Duas cidades; Ed. 34, 2002.

CANDIDO, Antonio. "Os fundamentos do poema: o ritmo". O estudo analítico do poema. 4. ed. São Paulo: Humanitas, 2004.

CANDIDO, Antonio. "Pressupostos". Formação da literatura brasileira: momentos decisivos. 5. ed. Belo Horizonte: Ed. Itatiaia; São Paulo: Edusp, $1975,1^{\circ} \mathrm{v}$.

CHKLÓVSKI, Viktor. "A arte como procedimento". Teoria da literatura: formalistas russos. Trad. Regina Zilberman et al. Porto Alegre: Globo, 1971. 
FREIXIEIRO, Fábio. Da razão à emoção II. Rio de Janeiro: Tempo brasileiro; INL, 1971.

FRYE, Northrop. "O mythos do inverno: ironia e sátira". Anatomia da crítica: quatro ensaios. Trad. Marcus de Martini. São Paulo: É Realizações, 2013.

GINZBURG, Carlo. "Estranhamento: pré-história de um procedimento literário". Olhos de madeira. Nove reflexões sobre a distância. Trad. Eduardo Brandão. São Paulo: Companhia das letras, 2001.

JAKOBSON, Roman. "Linguística e poética". Linguística e comunicação. Trad. Isidoro Blikstein e José Paulo Paes. São Paulo: Cultrix; Edusp, 1969. KAYSER, Wolfgang. "A estrutura do gênero". Análise e interpretação da obra literária. Trad. Paulo Quintela. Coimbra: Arménio Amado, 1985 (7ª ed.).

LE CORBUSIER. Por uma arquitetura. Trad. Ubirajara Rebouças. São Paulo: Perspectiva, 1977 ( $2^{\mathrm{a}}$ ed.).

LIMA, Luiz Costa. "A traição consequente ou a poesia de Cabral". Lira e antilira: Mário, Drummond, Cabral. 2. ed. rev. Rio de Janeiro: Topbooks, 1995. NUNES, Benedito. João Cabral: a máquina do poema. Org. Adalberto Müller. Brasília: Ed. UnB, 2007.

SECCHIN, Antonio Carlos. "O poema em trânsito (A educação pela pedra)". João Cabral: a poesia do menos. São Paulo: Duas Cidades; Brasília: INL; Fundação Nacional Pró-Memória, 1985.

SÜSSEKIND, Flora (org.). Correspondência de Cabral com Bandeira e Drummond. Rio de Janeiro: Nova fronteira; Edições Casa de Rui Barbosa, 2001.

SWIFT, Jonathan. Modesta proposta para evitar que as crianças da Irlanda sejam um fardo para os seus pais ou para o seu país. Trad. Dorothée de Bruchard [edição bilíngue]. Porto Alegre: Ed. Paraula, 1993.

Ariovaldo Vidal é professor doutor do Departamento de Teoria Literária e Literatura Comparada da Faculdade de Filosofia, Letras e Ciências Humanas da Universidade de São Paulo. Publicou os livros Roteiro para um narrador (2000), Leniza \& Elis (2002) em parceria, e Atando as pontas da vida (no prelo). Trabalha com a prosa brasileira moderna, a poesia brasileira do mesmo período, bem como com as relações entre literatura e cinema, procurando compreender a poética do autor em suas implicações com a tradição literária e a matéria social. Contato: ari.vidal@usp.br

ORCiD: https:// orcid.org/0000-0002-2132-0332 